\title{
MENGEKSPLORASI STRATEGI MANAJEMEN KELAS BAHASA INGGRIS DI SEKOLAH DASAR INKLUSI
}

\author{
Cicih Wiarsih ${ }^{1}$, Feisal Aziez ${ }^{2}$
}

${ }^{1,2}$ Universitas Muhammadiyah Purwokerto

\section{Article Info}

Article history:

Accepted April 22, 2021

Published April, 2021

\section{Keywords:}

Strategy

Classroom Management

English

Inclusive

\begin{abstract}
This research aims at: (1) exploring classroom management strategies used by English teachers in inclusive elementary school in Banyumas regency, (2) exploring English teachers' reasons in using the strategies in their inclusive classes, (3) exploring how English teachers accommodate various needs of students with special needs in the classroom. This is a descriptive qualitative research. The primary data was gathered through classroom observation while secondary data was collected through interviews. This research was done in two inclusive elementary schools in Banyumas regency. This study shows that English teachers in the school have good understanding on classroom management. However, the practice in the classroom indicates that there are still rooms for improvement.
\end{abstract}

Copyright $@ 2021$ FKIP UMP

All right reserved

\section{Corresponding Author:}

Cicih Wiarsih,

Program Studi Pendidikan Guru Sekolah Dasar,

Universitas Muhammadiyah Purwokerto,

Jl. KH. Ahmad Dahlan, Po. Box 202 Purwokerto, Banyumas, Indonesia.

Email: cicihwiarsih.umpwt@gmail.com

\section{How to Cite:}

Wiarsih, C., \& Aziez, F. (2021). Mengeksplorasi Strategi Manajemen Kelas Bahasa Inggris di Sekolah Dasar Inklusi. Khazanah Pendidikan-Jurnal Ilmiah Kependidikan (JIK), 15(1), 74-83. 


\section{PENDAHULUAN}

Dalam rangka pelaksanaan pembelajaran bahasa yang efektif di kelas, guru harus memiliki keterampilan untuk melakukan peran-peran yang beragam. Marzano (2003:1) menyebutkan bahwa dari sekian banyak peran penting guru di kelas, peran guru sebagai manajer adalah salah satu yang paling penting karena sebagaimana yang ia sampaikan bahwa "kelas yang dikelola dengan baik akan menyalakan suasana yang mendukung bagi pengajaran dan pembelajaran". Secara spesifik, di tingkat pendidikan dasar, Cotter (2011: 1) menyatakan bahwa manajemen kelas sangatlah penting karena kelas yang dikelola dengan tidak baik tidak akan mampu berjalan dengan efektif. Manajemen kelas yang buruk juga akan menghambat siswa dalam mencapai potensi tertinggi mereka. Ia juga mengklaim bahwa atmosfir yang positif dan menyenangkan harus diciptakan dalam kelas sekolah dasar untuk menciptakan pembelajaran yang aktif. Oleh karena itu, hal yang penting bagi para guru untuk mengenal manajemen kelas dengan baik dalam mata pelajaran apapun termasuk Bahasa Inggris.

Isu inklusi sendiri berkembang seiring dengan berkembangnya ide bahwa masingmasing individu memiliki hak yang sama untuk memperoleh pendidikan yang layak. Dixon (1999) melaporkan bahwa di Amerika Serikat inklusi diterima dan dilaksanakan secara luas sebagaimana ditunjukkan dengan jumlah siswa berkebutuhan khusus berusia 6-21 tahun yang menerima layanan pendidikan di kelas-kelas regular meningkat dari $28,8 \%$ di tahun ajaran 1987-1988 menjadi 44.5\% di tahun ajaran 1994-1995. Di Indonesia, pendidikan inklusi adalah termasuk hal yang baru. Seiring tuntutan kelompok difabel dalam menyuarakan hak-haknya, maka kemudian muncul konsep pendidikan inklusi. Salah satu kesepakatan Internasional yang mendorong terwujudnya sistem pendidikan inklusi adalah Convention on the Rights of Person with Disabilities and Optional Protocol yang disahkan pada Maret 2007. Pada pasal 24 dalam konvensi ini disebutkan bahwa setiap negara berkewajiban untuk menyelenggarakan sistem pendidikan inklusi di setiap tingkatan pendidikan. Adapun salah satu tujuannya adalah untuk mendorong terwujudnya partisipasi penuh difabel dalam kehidupan masyarakat. Namun dalam prakteknya sistem pendidikan inklusi di Indonesia masih menyisakan persoalan tarik ulur antara pihak pemerintah dan praktisi pendidikan, dalam hal ini para guru.

Praktik pembelajaran tentu akan berhasil dengan baik jika didukung dengan sumber daya manusia dalam hal ini guru yang memiliki kemampuan mengatur, mengondisikan, dan mengawasi proses pembelajaran. Kemampuan tersebut disebut dengan istilah manajemen kelas.

Istilah manajemen kelas dapat dilihat dari sisi beberapa perspektif. Definisi sempit dari manajemen kelas melihat hal ini hanya sebagai "disiplin dan manajemen perilaku siswa" (Allen, 2010: 2). Definisi serupa disampaikan Kratochwill (2014) yang mengatakan bahwa manajemen kelas mengacu pada disiplin kelas. Pandangan-pandangan ini hanya menganggap manajemen kelas sebagai manajemen perilaku siswa yang fokus pada menjaga disiplin siswa di kelas. Dalam cakupan yang lebih luas dan praktis, Evertson \& Weinstein (Oliver, Wehby, \& Reschly, 2011: 7) mendefinisikan manajemen kelas sebagai "segala tindakan yang dilakukan guru dalam menciptakan lingkungan yang mendukung dan memfasilitasi siswa baik pembelajaran akademik maupun sosial-emosional. Dari sudut pandang serupa, Martin, Yin \& Baldwin (Yasar, 2008) mengartikan manajemen kelas secara komprehensif dimana manajemen kelas dipahami sebagai usaha guru untuk mensupervisi sejumlah aktivitas di kelas seperti pembelajaran, memonitor interaksi sosial, dan membimbing perilaku siswa. Dengan kata lain, manajemen kelas dapat dipahami sebagai segala usaha yang dilakukan secara aktif oleh guru untuk membantu siswa dalam proses pembelajaran di kelas baik secara akademis, sosial, maupun emosional. 
Guru akan mampu menyampaikan materi secara efektif jika menggunakan strategi yang efektif pula. Ben (Yasar, 2008: 1) mengemukakan bahwa strategi manajemen kelas yang efektif memberikan pengaruh yang penting bagi guru dalam penyampaian pengajaran efektif. Selain itu, Lewis (2009: 12) berpendapat bahwa setiap usaha yang dilakukan oleh guru mengenai manajemen kelas sangat membantu untuk membuat siswa sadar akan nilainialai seperti tanggung jawab, toleransi, kepedulian dan perhatian kepada orang lain, menghormati, dan kejujuran. Manajemen kelas berkontribusi terhadap pengajaran yang efektif dan penyampaian instruksi yang sukses.

Istilah strategi disini merujuk pada usaha yang dibuat oleh seluruh komunitas sekolah dalam mengatasi berbagai masalah dan/atau hambatan yang mungkin terjadi dalam konteks ruang kelas. Pengembangan yang menyeluruh dan tindakan-tindakan secara bertahap yang bertumpu pada tujuh unsur manajemen kelas efektif berbasis penelitian. Marzano (2003) menegmukakan tujuh unsur manajemen kelas yang merupakan peraturan dan prosedur, disiplin dan konsekuensi, hubungan guru-siswa, sistem mental, tanggung jawab siswa, memulai dengan baik, dan manajemen pada level sekolah. Karena penelitian ini bertujuan untuk melihat manajemen kelas yang dilakukan oleh guru dalam pembelajaran Bahasa Inggris di kelas, hanya tiga unsur manajemen kelas pertama yang ditekankan dalam pembahasan ini. Tiga unsur tersebut yaitu peraturan dan prosedur, disiplin, dan konsekuensi serta hubungan guru-siswa.

Marzano (2003:13) menyatakan bahwa salah satu bagian terpenting dari manajemen kelas yang efektif adalah rancangan peraturan dan prosedur. Selanjutnya, dijelaskan bahwa istilah peraturan dan prosedur memiliki beberapa perbedaan penting meskipun keduanya merujuk pada ekspektasi yang tertulis mengenai perilaku yang diharapkan. Menurutnya, ada beberapa strategi manajemen kelas yang dapat guru gunakan dalam merancang dan membuat peraturan dan prosedur di kelas. Secara lebih rinci, strategi ini dibagi menjadi enam pokok utama seperti perilaku umum di kelas yang diharapkan, permulaan dan akhir kelas atau periode, transisi dan interupsi, bahan dan peralatan, kerja kelompok, dan kerja dengan teman sebangku dan berbagai aktivitas yang dipimpin oleh guru.

Marzano (2003: 27) menyatakan bahwa kedisiplinan di sekolah harus diprioritaskan pertama kali oleh guru kelas, karena "setiap bentuk pelanggaran disipliner bukan hanya tidak efektif tetapi juga kontraproduktif bagi perilaku dan pencapaian siswa". Dalam memadukan kedisipinan, ia mengemukakan lima langkah pokok yang dapat dilakukan guru saat berhadapan dengan perilaku positif dan negatif siswa. Pertama, guru dapat menanggapi perilaku siswa dengan ucapan maupun perbuatan. Emmer, et al. (Marzano, 2003: 35) mengemukakan bermacam-macam tanggapan guru. Pertama, guru dapat mendekati siswa atau melihat siswa yang melakukan kesalahan secara langsung. Kedua, guru dapat menggelengkan kepala, menggerakkan jari, dan/atau menggerakan bibir untuk menunjuk perilaku siswa yang tidak seharusnya. Ketiga, jika siswa tetap berperilaku yang tidak seharusnya, berikan peringatan sederhana secara pribadi dan sehalus mungkin.

Solusi lain yang dikemukakan oleh Marzano (2003: 35) yaitu guru dapat mendukung siswa dalam persoalan kedisiplinan dengan memanfaatkan kesadaran nyata yang "melibatkan penggunaan beberapa simbol perilaku pantas yang konkret". Simbol konkret yang digunakan dalam strategi ini dapat diisyaratkan berupa bermacam-macam benda lain yang mana benda tersebut digunakan untuk mengindikasikan bahwa siswa tertentu berperilaku dengan baik. Ia juga menyatakan bahwa dalam menerapkan strategi ini di kelas, guru harus mengingat bahwa jenis strategi ini memerlukan penerapan yang berkelanjutan, bukan untuk tujuan insidental. Dengan kata lain, hanya siswa yang berperilaku baiklah yang akan mendapat pujian dan/atau apresiasi.

Strategi ketiga untuk menjaga perilaku siswa yaitu dengan akibat langsung. Menurut Marzano (2003: 37), strategi ini lebih fokus pada akibat negatif untuk perilaku siswa yang 
menyangkut akibat yang gamblang dan jelas bagi siswa yang Ianggap berperilaku buruk. Salah satu cara yaitu dengan memberi mereka isolation time out. Isolation time out merujuk pada pemindahan siswa dari kelasnya ke suatu tempat.

Unsur manajemen kelas efektif yang ketiga, setelah peraturan dan prosedur serta intervensi kedisiplinan, yaitu hubungan guru-siswa (Marzano, 2003: 41). Ia menyatakan bahwa hal tersebut layak untuk dipikirkan bahwa ketika siswa dan guru memiliki hubungan yang baik, akan lebih mudah bagi siswa untuk menerima peraturan, prosedur, dan tindakan kedisiplinan apapun di kelas. Ia menyebutkan ada beberapa cara yang dapat dilakukan untuk menciptakan proporsi ideal dominasi guru dan siswa di kelas.

Cara-cara tersebut menurut Emmer, et al (Marzano, 2003: 49-55) diantaranya: pertama, guru dapat menggunakan teknik tertentu untuk menunjukkan kewenangannya di kelas. Guru dapat menunjukkan ketegasan, tetapi tidak "merendahkan atau menyerang siswa". Langkah kedua yang dapat guru lakuan untuk menunjukkan kewenangannya di kelas yaitu dengan menggunakan "perilaku tertentu yang menunjukkan tingkat kerjasama yang baik", guru harus selalu memperhatikan setiap siswa di kelas dengan cara mencoba memahami minat setiap siswa. Terakhir, ketika guru memberikan feedback kepada siswa atau memperbaiki kesalahan siswa, guru harus melakukannya dengan cara yang baik agar siswa tidak merasa "diserang". Ia juga berpendapat bahwa guru harus lebih fokus dalam memberikan teladan yang baik daripada fokus memperbaiki kesalahan siswa.

Ketiga, dalam menunjukkan kewenangan di kelas, Marzano (2003: 55) menyatakan bahwa guru harus sadar akan kebutuhan siswa yang berbeda-beda. Ia menyebutkan bahwa setidaknya ada lima tipe siswa meliputi siswa pasif, siswa agresif, siswa yang memiliki permasalahan konsentrasi, siswa yang perfeksionis, dan siswa yang kurang cakap dalam bergaul.

Tentunya berbagai pembahasan di atas berkaitan dengan strategi manajemen kelas penting pula diterapkan dalam pembelajaran Bahasa Inggris di SD atau pembelajaran Bahasa Inggris sejak dini (Teaching English to Young Learners/ TEYL). TEYL secara sederhana dapat didefnisikan sabagai pengajaran bahasa Inggris pada anak usia dini. Sebagaimana dikemukakan oleh Cameron, (2001: 1), perbedaan yang terletak antara pembelajar dewasa dan anak-anak berasal dari perbedaan penting pada tiga aspek utama seperti bahasa, psikologi, dan perkembangan sosial. Cameron (2001) menyatakan bahwa memahami kebutuhan belajar siswa di TEYL merupakan bagian integral. Terkait hal ini, Ia menekankan bahwa guru harus tahu dan lebih fokus pada kebutuhan belajar siswa daripada materi yang ada di buku pelajaran atau minat pribadi guru mengenai cara mengajarnya. Dengan kata lain, ketika mengajarkan Bahasa Inggris kepada anak-anak, guru harus lebih memperhatikan bagaimana sebenarnya anak-anak mempelajari bahasa dan apa yang mereka butuhkan ketika mempelajari bahasa, bukan apa yang harus dipelajari anak-anak tersebut atau cara yang lebih disukai guru untuk mengajarkan bahasa.

Harmer (2001: 38) mengemukakan tujuh karakter dasar yang membedakan pembelajar bahasa anak-anak dan dewasa. Pertama, Ia berpendapat bahwa pembelajar usia dini akan memberikan tanggapan terhadap stimulus yang mereka dapatkan secara langsung meskipun mereka tidak memahami kata-katanya. Kedua, pembelajar usia dini seringkali mempelajari makna secara tidak langsung yang mereka ambil dari berbagai sisi, dari apapun yang ada disekitar mereka dan bukan berupa topik tertentu yang telah Iajarkan pada mereka. Ketiga, Harmer menyebutkan bahwa pembelajar usia dini memperoleh pemahaman mereka tidak hanya dari penjelasan orang lain namun juga dari apa yang mereka dengar, lihat, sentuh, atau hasil interaksi. Keempat, menurutnya, pembelajar usia dini mudah menunjukkan antusiasme dan rasa penasaran mereka mengenai sesuatu. Kelima, anak-anak "membutuhkan perhatian individu dan persetujuan dari gurunya". 
Harmer juga menjelaskan bahwa pembelajar usia dini hebat dalam berbicara mengenai diri mereka dan sangat tertarik pada sebuah pembelajaran yang menggunakan kehidupan mereka sebagai topik utamanya. Terakhir, pembelajar usia dini "memiliki durasi konsentrasi yang terbatas", maka dari itu mereka dapat dengan mudah merasa bosan.

Williams (2009: 172-184) mengategorikan anak-anak berkebutuhan khusus ke dalam beberapa kategori masalah seperti perkembangan, kelainan fisik dan mental, budaya dan lingkungan. Menurutnya, anak-anak yang dikategorikan kedalam permasalahan ini adalah mereka yang memiliki keterlambatan perkembangan atau mereka yang belum berkembang di tahap yang sama dengan anak sebaya dalam hal fisik dan akal seperti mereka yang dikategorikan sebagai slow learners. Ia juga menjelaskan bahwa anak-anak yang memiliki kelainan fisik dan mental adalah mereka yang mengalami keterlambatan fisik dan akal seperti penderita autisme, buta atau tuli. Selanjutnya, Ia menjelaskan bahwa anak-anak yang berhadapan dengan persoalan budaya adalah mereka yang menderita karena permasalahan budaya seperti bahasa di kelas. Terakhir, anak-anak yang diyakini memiliki permasalahan lingkungan adalah mereka yang memiliki masalah dengan lingkungan di luar sekoah sepertu mereka yang memiliki masalah keuangan, perceraian, dan yang mengalami penyiksaan fisik atau mental.

Disebutkan oleh Westwood (1997: 3), ada beberapa unsur penting dalam memfasilitasi anak-anak berkebutuhan khusus di sekolah inklusi dalam cakupan yang lebih luas di tingkat sekolah. Ia menambahkan bahwa unsur yang akan dijelaskan harus dilakukan secara kolaboratif oleh seluruh sistem sekolah. Pertama, kepemimpinan yang kuat harus dilakukan oleh kepala sekolah. Kedua, harus ada pengembangan kebijakan sekolah yang kuat tentang gagasan inklusi. Ketiga, harus ada pengembangan sikap positif yang serius terhadap siswa berkebutuhan khusus. Keempat, adanya komitmen di seluruh bagian staf untuk bekerja secara kolaboratif dan berbagi berbagai masalah, tanggung jawab dan keahlian jelas dibutuhkan. Kelima, membina jaringan yang mendukung menjadi hal yang penting Iantara staf dan bekerjasama dengan lembaga dan layanan lain seperti layanan pemerintah. Keenam dan ketujuh, harus ada sumber pemasukan yang cukup terkait materi dan personil serta pelatihan reguler dan pengembangan profesional bagi staf pengajar. Kedelapan, sekolah harus memiliki hubungan yang dekat dengan orang tua. Terakhir, harus ada penyesuaian kurikulum dan metode mengajar yang efektif.

Guna memfasilitasi anak-anak berkebutuhan khusus di dalam kelas, Westwood (1997: 7) mengemukakan sebuah solusi untuk guru yang disebut 'individualized programming'. Istilah ini berarti bahwa guru disarankan untuk mengakomodasi perbedaan individual siswa, meliputi siswa yang memiliki keterbatasan yang cukup signifikan dan permasalahan dalam belajar. Ia menyebutkan bahwa hal ini bukan berarti guru harus memberikan setiap anak tugas individual selama pembelajaran, akan tetapi hal ini dapat dilakukan dengan mengharapkan hasil yang bervariasi dari para siswa berdasarkan kemampuan setiap siswa dalam belajar. Dengan kata lain, guru dapat memberikan tugas yang sama namun penilaian dilakukan secara individu tergantung kemampuan belajar siswa.

Williams (2009) meyakini bahwa kolaborasi dengan guru pendidikan-khusus dan terapis akan sangat penting dalam membantu anak-anak berkebutuhan khusus di dalam kelas. Dengan kata lain, penting bagi guru dan sekolah untuk mulai mengembangkan program individual yang dapat mengakomodasi setiap siswa berkebutuhan khusus berdasarkan kategori kebutuhan khusus masing-masing siswa.

Corbett (2001: 13) berpendapat bahwa "pendidikan inklusi harus dapat bekerja dan memberikan nilai yang baik terkait kualitas pengalaman belajar bagi semuanya.". Corbett juga mengklaim bahwa munculnya pendidikan inklusi bertumpu pada "trend awal tentang integrasi yang mainstream dari siswa berkebutuhan khusus, yang menyajikan anggapan 
bahwa semua siswa memiliki hak untuk dididik di sekolah reguer dan untuk memperoleh kesempatan yang sama untuk berpartisipasi dalam kurikulum reguler" (Westwood, 1997: 3). Oleh karena itu, dalam hal ini, adanya anak-anak berkebutuhan khusus merupakan salah satu faktor yang berkontribusi terhadap ide inklusi.

Kesimpulannya, gagasan pendidikan inklusi tidak hanya tentang memberikan kesempatan yang sama kepada anak-anak berkebutuhan khusus tetapi juga terkait dengan cakupan yang lebih luas lagi seperti kesetaraan bagi seluruh pelajar dan jaminan bagi semua orang terkait mutu pembelajaran.

sarana dan prasarana yang minim sebagai penunjang sistem pendidikan inklusi serta terbatasnya pengetahuan yang dimiliki oleh para guru di sekolah-sekolah inklusi menunjukkan bahwa sistem ini masih perlu pengembangan. Penelitian menjadi salah satu jalan untuk mengembangkan sistem pendidikan ini kearah yang lebih baik. Oleh karena itu, penelitian ini berupaya mengeksplorasi praktik manajemen kelas Bahasa Inggris di sekolah inklusi terutama yang berada di Kab. Banyumas. Hasil penelitian ini diharapkan dapat menjadi cerminan praktik sistem pendidikan inklusi khususnya dalam kelas Bahasa Inggris. Adapun tujuan penelitian ini adalah untuk: (1) mengeksplorasi strategi manajemen kelas yang digunakan guru di sekolah dasar inklusi di Kab Banyumas, (2) mengeksplorasi alasan guru menggunakan strategi manajemen kelas tertentu, (3) mengeksplorasi bagaimana guru mengakomodasi kebutuhan siswa inklusi yang beragam dalam proses pembelajaran bahasa Inggris.

\section{METODOLOGI}

Penelitian ini menggunakan metode deskriptif dengan pendekatan kualitatif. Sebagaimana yang disampaikan Denzin \& Lincoln (2000, in Ospina, 2003: 3) bahwa penelitian kualitatif melibatkan pendekatan naturalistik dan interpretif yang dilakukan dalam situasi alaminya dan jenis penelitian ini juga biasanya digunakan untuk memahami fenomena tertentu. Penelitian kualitatif juga umumnya digunakan untuk menginvestigasi informasi mendetil tentang sebuah fenomena tertentu (Creswell, 2008: 51). Data penelitian ini dikumpulkan melalui observasi di kelas dan juga wawancara terhadap guru. Observasi di kelas digunakan untuk mengumpulkan data mengenai proses pembelajaran di kelas terutama dalam hal strategi manajemen kelas yang digunakan oleh guru dalam mata pelajaran bahasa Inggris. Wawancara dengan guru dengan pertanyaan terbuka (open-ended questions) kemuIan digunakan pula dalam penelitian ini. Pertanyaan-pertanyaan yang digunakan bertujuan untuk mengeksplorasi pendapat dan alasa guru mengenai strategi manajemen kelas yang mereka gunakan dalam pembelajaran bahasa Inggris di kelas mereka.

Penelitian ini dilakukan di dua sekolah dasar inklusi di Kabupaten Banyumas, Jawa Tengah. Sekolah pertama terletak di Kecamatan Tanjung dan sekolah kedua terletak di Kecamatan Teluk. Kedua sekolah ini dipilih karena merupakan kedua sekolah tersebut merupakan sekolah dasar inklusi pertama yang ada di Kabupaten Banyumas. Setiap tahunnya, kedua sekolah ini mengalokasikan sebagian kapasitasnya untuk anak-anak berkebutuhan khusus. Sebagai tambahan, kedua sekolah ini juga dikenal dengan siswanya yang memiliki latar belakang sosio-ekonomi yang berbeda. Subjek dari penelitian ini adalah para guru bahasa Inggris di kedua sekolah tersebut. 


\section{HASIL DAN PEMBAHASAN}

Berdasarkan hasil wawancara dengan kepala sekolah menjelaskan bahwa semenjak pendidikan inklusif diterapkan sekolah diharuskan untuk menerima siswa yang memiliki kebutuhan khusus. Setelah program inklusi dijalankan, sekolah tersebut akhirnya dapat menciptakan konsensus tingkat sekolah yang secara khusus terkait dengan pendaftaran yang diakui oleh semua pihak, seperti batas IQ minimum 80 untuk anak-anak berkebutuhan khusus. Selain itu, pernyataan resmi mengenai kategorisasi setiap jenis kebutuhan khusus siswa harus berasal dari psikolog (misalnya autisme, pelajar lambat, dll.). Sekolah dasar inklusi juga mendapat dukungan finansial tambahan dari pemerintah yang dimaksudkan untuk mendorong pendidikan inklusi.

Ketika guru bahasa Inggris diminta untuk mendefinisikan manajemen kelas, mereka memberi jawaban yang tidak pasti. Salah satu guru mendefinisikan manajemen kelas sebagai 'cara untuk mengelola kelas' dan guru lain mendefinisikannya sebagai 'keterampilan guru untuk mengelola perilaku kelas atau untuk mengambil alih kondisi kelas untuk mengelola dan mengendalikan siswa'. Secara umum, meskipun kedua guru tersebut tidak dapat mendefinisikan manajemen kelas secara tepat, mereka berbagi gagasan yang sama tentang siswa yang memiliki berbagai kebutuhan di kelas. Tanpa diduga, hanya salah satu guru yang disebutkan atau manajemen kelas terkait dengan disiplin seperti Allen (2010) dan Tauber (2007) yang berpendapat bahwa manajemen kelas terkait erat dan bahkan setara dengan kedisiplinan.

Semua guru dalam penelitian ini menafsirkan pendidikan inklusif sebagai pendidikan untuk anak berkebutuhan khusus yang berlangsung di kelas dengan anak normal. Temuan ini memperkuat pendapat Ainscow (2002: 219) yang menyatakan bahwa inklusi atau pendidikan inklusi berarti memindahkan atau membawa anak dengan kebutuhan khusus dari sekolah khusus ke sekolah umum dan 'memasukkan' mereka ke dalam kegiatan belajar. Kemudian, ketika ditanya tentang perbedaan antara kelas inklusif dan ruang kelas utama atau kelas reguler, semua guru masih menggunakan anak-anak dengan kebutuhan khusus sebagai unsur pembeda yang membedakan antara kelas inklusif dan kelas reguler. Kehadiran anak-anak dengan kebutuhan khusus masih menjadi titik penentu untuk membedakan dua jenis pendidikan ini, hanya satu guru yang menambahkan 'berbagai kebutuhan para siswa' saat menjelaskan tentang perbedaan antara kelas inklusif dan reguler. Hal ini menunjukkan bahwa guru tersebut memiliki sebuah gagasan bahwa inklusi tidak hanya dijustifikasi karena ada anak-anak dengan kebutuhan khusus disitu tetapi juga "menitik beratkan kepada mengenali kebutuhan setiap individu yang berbedabeda" (Corbett, 2001: 11).

Para guru meyakini bahwa dengan diterapkannya pendidikan inklusif, anak berkebutuhan khusus akan mendapatkan kesempatan untuk memperoleh pendidikan yang sama dengan mereka yang tanpa kebutuhan khusus. Kesimpulannya, mereka sepakat bahwa pendidikan inklusif adalah cara untuk memberikan kesetaraan dalam hal memperoleh akses pendidikan. Gagasan ini juga serupa dengan pernyataan Ainscow (2002: 218) yang menyatakan bahwa inklusi adalah proses untuk meningkatkan partisipasi siswa dan juga mengurangi pengecualian mereka dari budaya, kurikulum, dan masyarakat seperti sekolah. Akan tetapi, mereka juga mengakui bahwa menerapkan inklusi bukanlah tugas yang mudah karena membutuhkan usaha dan tenaga ekstra. Mereka juga mengakui bahwa masih banyak hal yang belum mereka ketahui seperti pengetahuan tentang metode pengajaran, bahan ajar, pengetahuan tentang siswa dengan kebutuhan khusus, alat bantu pengajaran, dan banyak hal lainnya karena kurangnya pengetahuan dan pengalaman mereka dalam memberikan pendidikan inklusif. Oleh karena itu, mereka berharap bisa 
mendapatkan lebih banyak pengetahuan melalui workshop, pelatihan, seminar, atau lesson study.

Para guru mengakui bahwa pada saat ini, mereka tidak memiliki aturan pasti. Keduanya sama-sama menyatakan bahwa sebagian besar peraturan ditetapkan oleh sekolah. Sehubungan dengan prosedur, tidak satu pun guru bahasa Inggris memberi contoh prosedur tertentu yang biasanya mereka berikan kepada siswa. Meskipun mereka mengatakan bahwa ada beberapa peraturan di kelas, guru tersebut sepertinya tidak menunjukkan kembali dan atau mengulanginya di kelas. Tidak sekali pun, mereka mengingatkan siswa tentang peraturan dan prosedur tertentu. Dari enam masalah yang umum dibahas, hanya dua yang dibahas, seperti ekspektasi mengenai perilaku dan membuat peraturan pada awal periode. Dalam pengertian ini, manajemen kelas yang efektif belum digalakkan di kelas mereka karena perencanaan dan penerapan peraturan dan prosedur masih sangat rendah. Marzano, et al. (2003: 13) berpendapat bahwa karakteristik yang dapat diamati dari manajemen kelas yang efektif memerlukan perencanaan dan pelaksanaan peraturan dan prosedur kelas.

Pada pertemuan pertama, fokus utama mereka ada pada penyampaian peraturan umum yang umumnya dinyatakan dan diterapkan di seluruh sekolah, meninjau pelajaran sebelumnya, dan menginformasikan siswa tentang kegiatan yang akan datang di semester berikutnya. Selain itu, berdasarkan pengamatan, para guru sengaja menyampaikan tujuan hanya dalam empat pertemuan.

Secara khusus terkait dengan transisi dan interaksi, tidak ada satupun guru yang menyatakan bahwa mereka memiliki peraturan khusus yang berubungan dengan masalah ini. Meskipun dalam wawancara satu guru menyebutkan bahwa di kelasnya, para siswa sebelumnya diminta membawa kamus, namun kebijakan ini tidak diterapkan lagi. Dia tidak memberikan jawaban pasti terkait hal ini. Demikian pula, selama wawancara, guru lain menyebutkan bahwa dia meminta murid-muridnya untuk menggunakan bahasa Inggris untuk meminta izin untuk menggunakan kamar mandi. Namun, karena dia mengatakan bahwa para siswa membutuhkan waktu yang lama untuk mengatakan sesuatu dalam bahasa Inggris, dia akhirnya memutuskan untuk tidak menerapkannya lagi karena memerlukan waktu terlalu banyak dan mengganggu proses belajar. Dari tujuh area utama penggunaan peraturan dan prosedur dalam transisi dan interaksi di tingkat sekolah dasar yang diusulkan oleh Marzano, et al. (2003: 21), hanya ada empat area yang ter-cover, seperti meninggalkan ruangan, kembali ke kamar, penggunaan kamar mandi, dan penggunaan taman bermain.

Selain itu, karena para guru jarang menggunakan perangkat belajar tambahan disamping yang mereka tulis di papan tulis, tidak banyak peraturan dan prosedur yang berkaitan dengan materi dan perangkat. Mereka hanya menggunakan peraturan dan prosedur sederhana seperti meminta beberapa perwakilan untuk membagikan lembar ujikertas saat memeriksa hasil tes dan meminta siswa mengumpulkan pekerjaan mereka secara terpisah ke meja guru. Dalam wawancara, mereka mengakui bahwa mereka tidak menggunakan alat bantu pengajaran pendukung seperti bantuan visual, video, dan banyak hal lainnya karena mereka tidak memiliki cukup waktu dan sekolah tersebut tidak menyediakannya sehingga sulit bagi mereka untuk melakukannya.

Dari segi kerja kelompok, para guru tampaknya tidak memberi cukup kesempatan bagi siswa untuk bekerja dalam kelompok karena mereka meminta siswa untuk bekerja secara individu hampir di setiap pertemuan. Hal ini sangat disayangkan mengingat Marzano et al. (2003: 23) percaya bahwa kerja kelompok adalah aktivitas instruksional yang baik karena mempengaruhi prestasi belajar, hubungan interpersonal, dan sikap belajar. Secara khusus tentang seatwork dan kegiatan yang dipimpin oleh guru, setting tempat duduk di kelas adalah posisi duduk biasa dalam sistem pendidikan Indonesia 
dimana seluruh meja siswa menghadap meja guru yang ditempatkan di salah satu tepi depan kelas di dekat papan tulis. Ini mungkin berasal dari umumnya percaya bahwa pengaturan tempat duduk ini adalah cara paling efektif untuk membuat siswa lebih memperhatikan penjelasan guru. Seperti yang dikemukakan oleh Marzano, et al. (2003: 24), pengajaran kelas secara keseluruhan juga dipercaya sebagai cara terbaik untuk memberikan masukan bagi siswa. Selain itu, mereka menjelaskan bahwa seatwork dan kegiatan yang dipimpin oleh guru biasanya mewajibkan siswa untuk tetap berada di tempat duduk mereka.

\section{SIMPULAN DAN SARAN}

Secara umum, wawancara guru bahasa Inggris yang menjadi partisipan dalam penelitian ini menunjukkan bahwa guru sudah memahami makna pendidikan inklusi dan peran mereka dalam kelas. Akan tetapi, dalam pelaksanaan di kelas, guru masih belum dapat melaksanakan tugasnya dengan maksimal. Oleh karena itu, program sekolah inklusi sebaiknya terus dievaluasi oleh seluruh pihak yang terlibat secara berkelanjutan untuk perbaikan dan pengembangan ke arah yang lebih baik. Selain itu, disarankan juga agar para guru yang bekerja di lingkungan pendidikan inklusif diberi lebih banyak pelatihan, seminar, workshop atau lesson study untuk memperkaya pengetahuan mereka terhadap masalah inklusi dan pendidikan khusus. Fasilitas pembelajaran seperti buku dan realia juga perlu ditingkatkan agar bisa memaksimalkan proses pembelajaran siswa.

Selanjutnya, guru juga disarankan untuk dapat menjalankan perannya sebagai manajer kelas secara efektif terutama dalam mengelola perilaku siswa mereka di kelas. Karena para siswa berkebutuhan khusus yang ditugaskan ke dua kelas memiliki ketidakmampuan belajar ringan yang tidak memerlukan modifikasi instruksional yang ekstensif oleh para guru, penelitian selanjutnya mungkin mencakup kelas yang memiliki siswa dengan beragam kebutuhan khusus. Selain itu, penelitian selanjutnya juga diharapkan melibatkan pengamatan lebih ekstensif terutama di daerah lain di Indonesia.

\section{REFERENSI}

Allen, K.P. (2010). Classroom Management, Bullying, and Teacher Practices. The Professional Educator, Vol. 34, No. 1.

Cameron, L. (2001). Teaching languages to young learners. Cambridge: Cambridge University Press.

Corbett, J. (2001). Supporting inclusive education: A connective pedagogy. London: Routledge Falmer.

Cotter, K. (2011). Proper classroom management is essential for an effective elementary school classroom. Magister Theses, Honors Senior Theses, Paper 12.

Creswell, J.W. (2012). Educational research: Planning, conducting, and evaluation quantitative and qualitative research. New Jersey: Pearson Education, Inc.

Dixon Jr., J.A. (1999). A description of instructional practices in inclusive classroom settings. Doctoral Dissertation, unpublished, the Virginia Polytechnic Institute and State University.

Gall, M.G., Gall, J.P., \& Borg, W.R. (2003). Educational research: An introduction (7 $7^{\text {th }}$ ed.). New York: Pearson Education, Inc.

Harmer, J. (2001). The practice of English language teaching ( $3^{\text {rd }}$ ed.). London: Longman. Kratochwill, T. (2014). Classroom management. Accessed on December $16^{\text {th }}, 2015$, from http://www.apa.org/education/k12/classroom-mgmt.aspx. 
Lewis, R. (2009). Understanding pupil behavior: Classroom management techniques for teachers. New York: Routledge.

Lichtman, M. (2013). Qualitative research in education: A user's guide ( $3^{\text {rd }}$ ed.). London: Sage Publications, Inc.

Marzano, R.J. (2003). Classroom management that works: Research-based strategies for every teacher. Virginia: Association for Supervision and Curriculum development (ASCD).

Oliver, R.M., Wehby, J.H., \& Reschly, D.J. (2011). Teacher classroom management practices: Effects on disruptive or aggressive student behavior. Campbell Systematic Reviews, 2011:4.

Ospina, M. (2004). Qualitative Research. The EncyclopeIa of Leadership, SAGE Publications, 2004.

Patton, J.R., et al. (1987). Exceptional children in focus (4 $4^{\text {th }}$ ed.). Columbus, OH: Merrill Publishing.

Westwood, P. (1997). Commonsense methods for children with special needs ( $3^{\text {rd }}$ ed.). New York: Routledge.

Williams, K.C. (2009). Elementary classroom management: A student-sentered approach to leading and learning. California: SAGE Publications Inc.

Yasar, S. (2008). Classroom management approaches of primary school teachers. Magister Thesis, unpublished, Middle East Technical University, Ankara.

Yin, R.K. (2011). Qualitative research from start to finish. New York: The Guilford Press.

\section{http://jurnalnasional.ump.ac.id/index.php/khazanah}

